\title{
Рецензия. Book Review
}

\section{Донная фауна залива Нячанг, Южный Вьетнам. М.: Т-во Научных изданий КМК. 2007. 249 с. (под ред. Т.А. Бритаева и Д.С. Павлова) (на англ. языке). \\ Benthic fauna of the Bay of Nhatrang, Southern Vietnam. Moscow: KMK Scientific Press Ltd. 2007. 249 p. (eds. T.A. Britayev, D.S. Pavlov) (in English).}

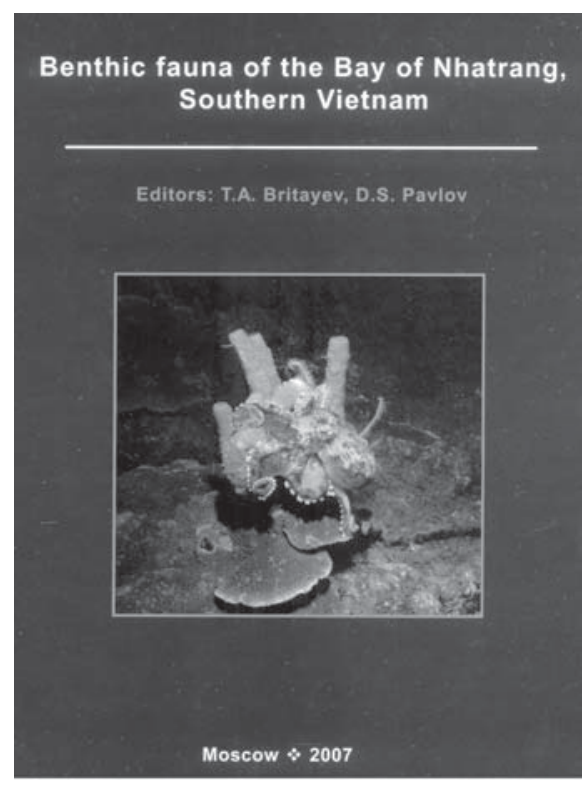

Научное сотрудничество между Россией и Вьетнамом имеет давнюю историю. Выдающийся российский зоолог и эмбриолог К.Н. Давыдов, оказавшийся в эмиграции, много лет работал в Индокитае еще в 20-е и 30-е годы прошлого века и был в числе создателей Океанографического Института в Нячанге, на базе которого впоследствии (уже в независимом Вьетнаме) возник Институт морских исследований. Совместные советско-вьетнамские исследования начались в Нячанге после 1975 г. В них с советской стороны принимали участие Институт биологии моря Дальневосточного отделения АН СССР,Институт эволюционной морфологии и экологии животных им. А.Н. Северцова АН СССР (ныне Институт проблем экологии и эволюции РАН) и другие институты АН СССР. С 1988 г. в Нячанге функционирует Российско-Вьетнамский
Тропический научно-исследовательский и технологический центр, на базе которого проводятся исследования по широкому кругу биологических проблем.

Изучение богатейшей морской фауны Вьетнама всегда было одним из главных направлений совместных российско-вьетнамских исследований. За три десятилетия вышло около двух десятков сборников и монографий по фауне, экологии и перспективам практического использования морской биоты Вьетнама, однако рецензируемая книга занимает особое место. Она опубликована на английском языке, что делает ее неизмеримо более доступной для широкого круга биологов, чем предыдущие сборники и монографии, которые публиковались преимущественно по-русски с краткими аннотациями на английском и вьетнамском языках. 
Книга содержит 8 глав, каждая из которых представляет собой аннотированный список видов животных той или иной систематической группы. Глава 1 посвящена склерактиниям и миллепоридам, глава 2 - сипункулидам, глава 3 - усоногим ракам, глава - 4 ракам-богомолам (Stomatopoda), главы 5, 6, 7 - нескольким группам десятиногих ракообразных, глава 8 - кремнероговым губкам (Demospongia). Авторы соответствующих глав - специалисты из России, Вьетнама и Чехии. В этих главах описаны 195 видов кораллов (1 вид оказался новым для науки), 8 видов сипункулид, 32 вида усоногих ракообразных, 21 вид Stomatopoda, 52 вида креветок, 26 видов крабов и 89 видов губок. Описания многих видов снабжены иллюстрациями, которые в своем большинстве представляют собой цветные фотографии высокого качества.

Следует отметить, что степень подробности описаний в разных главах не одинакова. Так, глава 1 представляет собой иллюстрированный атлас склерактиний, миллепорид и гелиопорид с краткими морфологическими описаниями и фотографиями живых кораллов, что позволяет предваритель- но определять материал в полевых условиях. Глава 2 - это аннотированный список сипункулид, в котором сделаны заметки по распределению и плотности, но отсутствуют морфологические описания и иллюстрации. В то же время, глава 3 представляет собой полноценную таксономическую работу, в которой приведен ключ для определения усоногих ракообразных окрестностей Нячанга. А что касается главы 8, - это предварительный список видов губок Demospongia, основная работа с которыми еще впереди.

И все же, оценивая книгу в целом, следует охарактеризовать ее как весьма полезное издание, которым смогут пользоваться зоологи и гидробиологи многих стран. Будем надеяться, что рецензируемая книга - только начало и что вслед за ней последует целая серия фундаментальных хорошо иллюстрированных изданий по морской фауне Вьетнама, которые со временем станут основным руководством по изучению биологического разнообразия этого уникального региона нашей планеты.

В.В. Малахов 